\title{
New Palaeolithic and Mesolithic sites in the eastern Aegean: the Karaburun Archaeological Survey Project
}

\author{
Ç. Çilingiroğlu ${ }^{1, *}$, B. Dinçer ${ }^{2}$, A. Uhri ${ }^{3}$, C. Gürbıyık ${ }^{4}$, İ. Baykara ${ }^{5}$ \\ \& C. Çakırlar ${ }^{6}$
}

\section{Research aim and significance}

Despite ongoing fieldwork focusing on the Palaeolithic and Mesolithic periods of the Aegean, the eastern part of this region, especially western Turkey, remains almost entirely unexplored in terms of early prehistory. There is virtually no evidence from this area that can contribute to broader research themes such as the dispersal of early hominins, the distribution of Early Holocene foragers and early forager-farmer interactions. The primary aim of the Karaburun Archaeological Survey Project is to address this situation by collecting data from the eastern side of the Aegean Sea, thereby contributing to the currently debated issues of Aegean and Eastern Mediterranean prehistory.

\section{The survey area}

The Karaburun Peninsula occupies a strategic position in the eastern Aegean and lies close to the modern city of Izmir (Figure 1). Prior to the current project, limited archaeological research had been undertaken in this region, emphasising its rugged terrain, the thick cover of Mediterranean evergreen vegetation and low surface visibility. The Karaburun Archaeological Survey Project commenced in 2015 and is the first to investigate this 'difficult' landscape systematically.

The project is designed as a pedestrian survey with both extensive and intensive strategies. The team documents all traces of past human activity using standard recording forms noting geological, geomorphological, vegetational and archaeological information. The first season

1 Ege University, Faculty of Letters, Department of Protohistory and Near Eastern Archaeology, 35100 BornovaIzmir, Turkey (Email: ciler.cilingiroglu.unlusoy@ege.edu.tr)

2 Istanbul University, Faculty of Letters, Prehistory Department, 34134 Laleli-Istanbul, Turkey (Email: berkay.dincer@istanbul.edu.tr)

3 Dokuz Eylül University, Faculty of Arts and Sciences, Department of Archaeology, 35260 Buca-Izmir, Turkey (Email:ahmet.uhri@deu.edu.tr)

4 Celal Bayar University, Faculty of Arts and Sciences, Department of Art History, 45140 Manisa, Turkey (Email: cengiz.gurbiyik@cbu.edu.tr)

5 Van Yüzüncü Yal University, Faculty of Letters, Department of Anthropology, 65080 Van, Turkey (Email: ibaykara@yyu.edu.tr)

6 Groningen Institute of Archaeology, Poststraat 6, NL-9712 ER, Groningen, The Netherlands (Email: c.cakirlar@rug.nl)

* Author for correspondence 


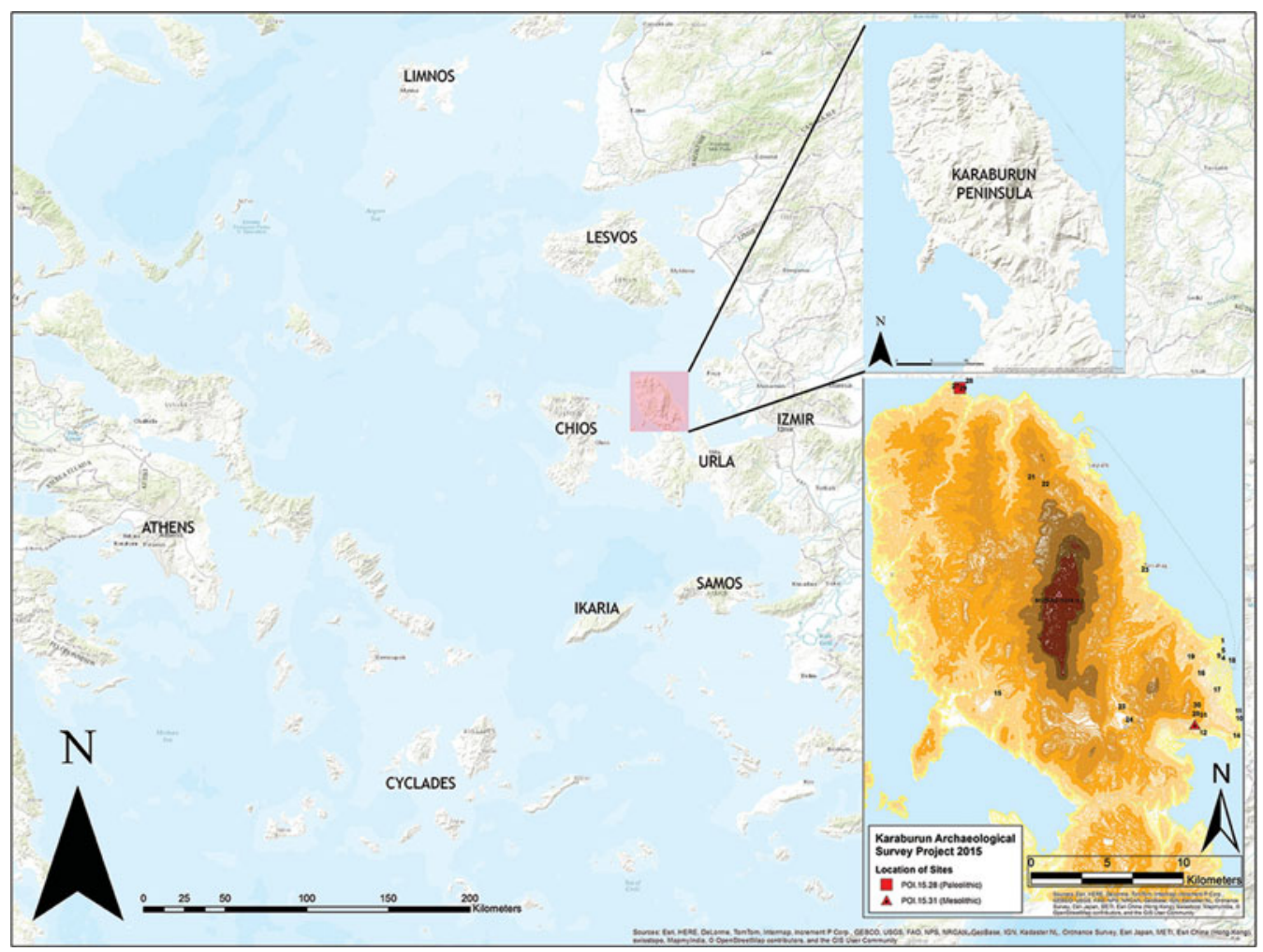

Figure 1. The location of Karaburun Peninsula in the Aegean and the map of the survey area with the sites mentioned in the text.

of fieldwork recorded 31 places with archaeological remains, including seven of prehistoric date (Figure 1). This article reports on the evidence for the earliest human activity identified so far at Karaburun.

\section{Lower Palaeolithic locality of Kömürburnu}

Prior to our survey, the earliest known site at Karaburun was limited to sporadic Neolithic and Chalcolithic findspots (Koşay \& Gültekin 1949; Uhri et al. 2010). The 2015 fieldwork identified artefacts of much earlier date. Pedestrian survey of the Kömürburnu localitya volcanic outcrop located on the northern coast of the peninsula (Figure 2) - collected a handaxe shaped from locally available andesite $(115 \times 65 \times 70 \mathrm{~mm})$. This is a biface, shaped by a hard hammer, and has a lenticular section and long S-shaped edge profiles (Figure 3). The tip and one edge are sharper; the other edge is irregularly shaped. The base of the biface is not significantly worked and bears $20-30$ per cent secondary cortex on each face. At this stage, it is not possible to give a precise date for this object, but based on its techno-typology, it is of Lower Palaeolithic age sensu lato. Associated with this biface, we also discovered cores and flakes.

(C) Antiquity Publications Ltd, 2016 


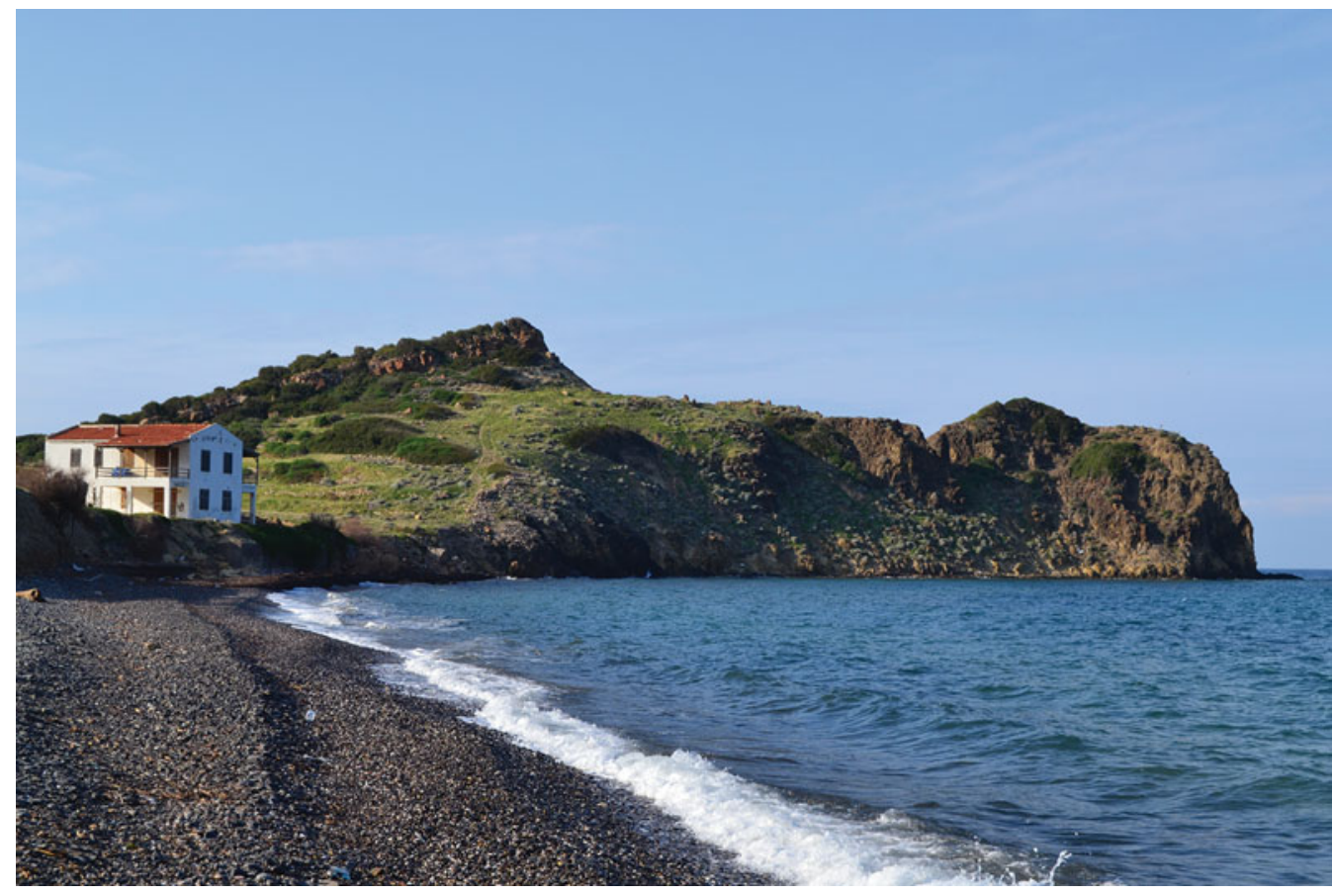

Figure 2. General view of the volcanic outcrops at Kömürburnu locality where Lower Palaeolithic activity has been identified (POI.15.28).

In the 1960s, non-systematic research in Izmir Province recovered two Palaeolithic handaxes. One of them has been attributed to the Lower Palaeolithic; it is a very large, flat and elongated flint biface with irregular edge profiles (Kansu 1963). The other biface is ovate in shape and relatively small; this has been attributed to the Micoquian and probably of Middle Palaeolithic date (Kansu 1969). Taking into account their technological properties, these two isolated finds from the neighbouring areas are different to the Karaburun biface. They do, however, reflect the presence of bifacial industries in this westernmost part of Anatolia, which may also be considered alongside the Acheulean site of Rodafnidia on Lesvos, especially when we consider the existence of a land bridge between these two localities during the Lower Palaeolithic (Galanidou et al. 2013).

\section{The Mesolithic findspot near Mordoğan}

The second early prehistoric findspot (POI.15.31) located during the 2015 work is a surface scatter of chipped stones found near limestone outcrops overlooking the Balıklıva Bay on the modern road from Mordoğan to Izmir. The chipped stones are produced from white patinated flint, and display a flake-based microlithic technology without the presence of geometrics. The collection of 116 lithics was found loosely scattered across the surface and seems to have been eroded from a location that remains undiscovered. The lithics represent a very crude, flake-based industry with few retouched specimens (Figure 4). Only 12 pieces

(C) Antiquity Publications Ltd, 2016 


\section{Ç. Çilingiroğgu et al.}
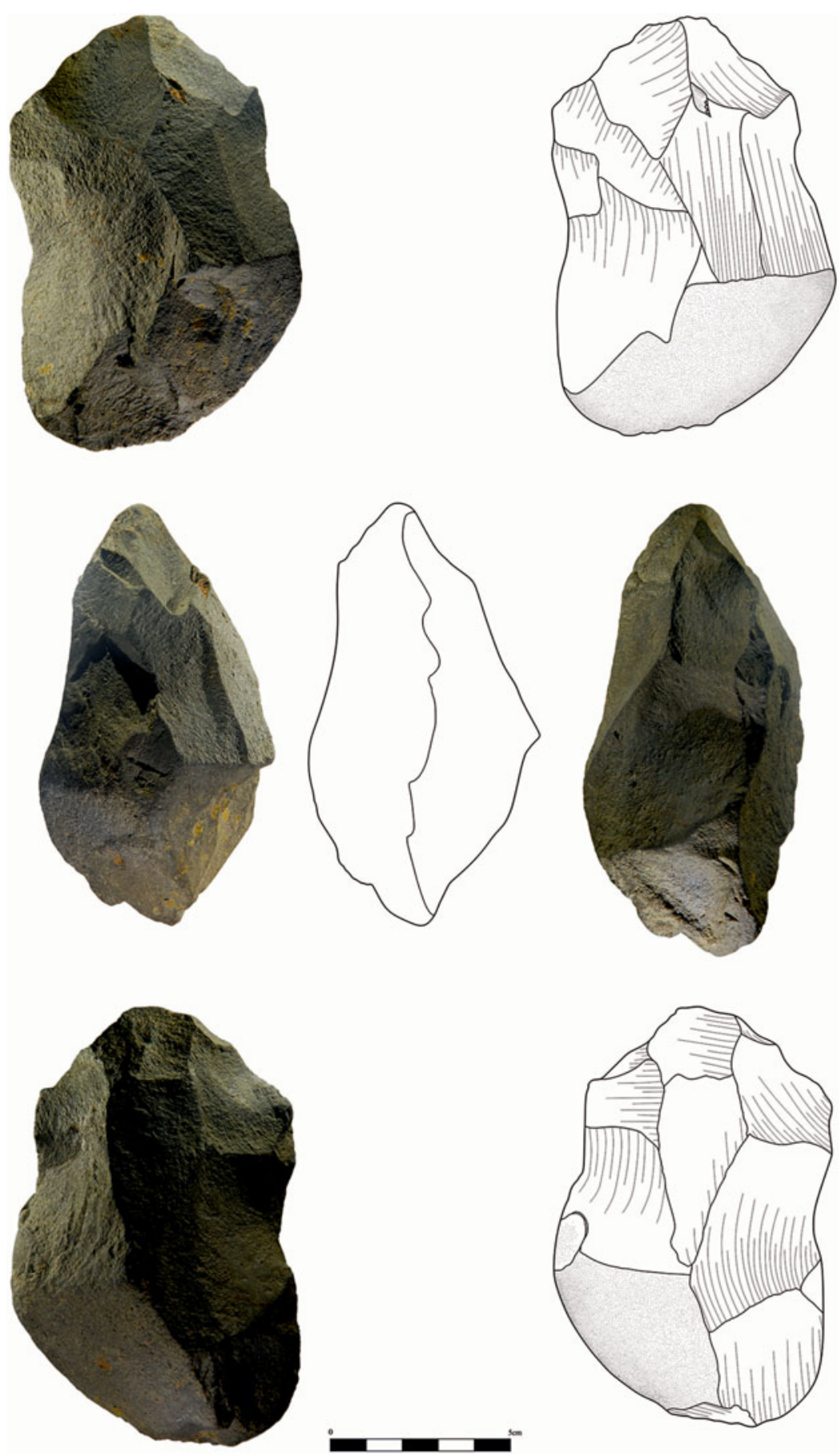

Figure 3. Lower Palaeolithic biface from POI.15.28 (drawing by G. Özçolak and E. Sezgin).

(C) Antiquity Publications Ltd, 2016 


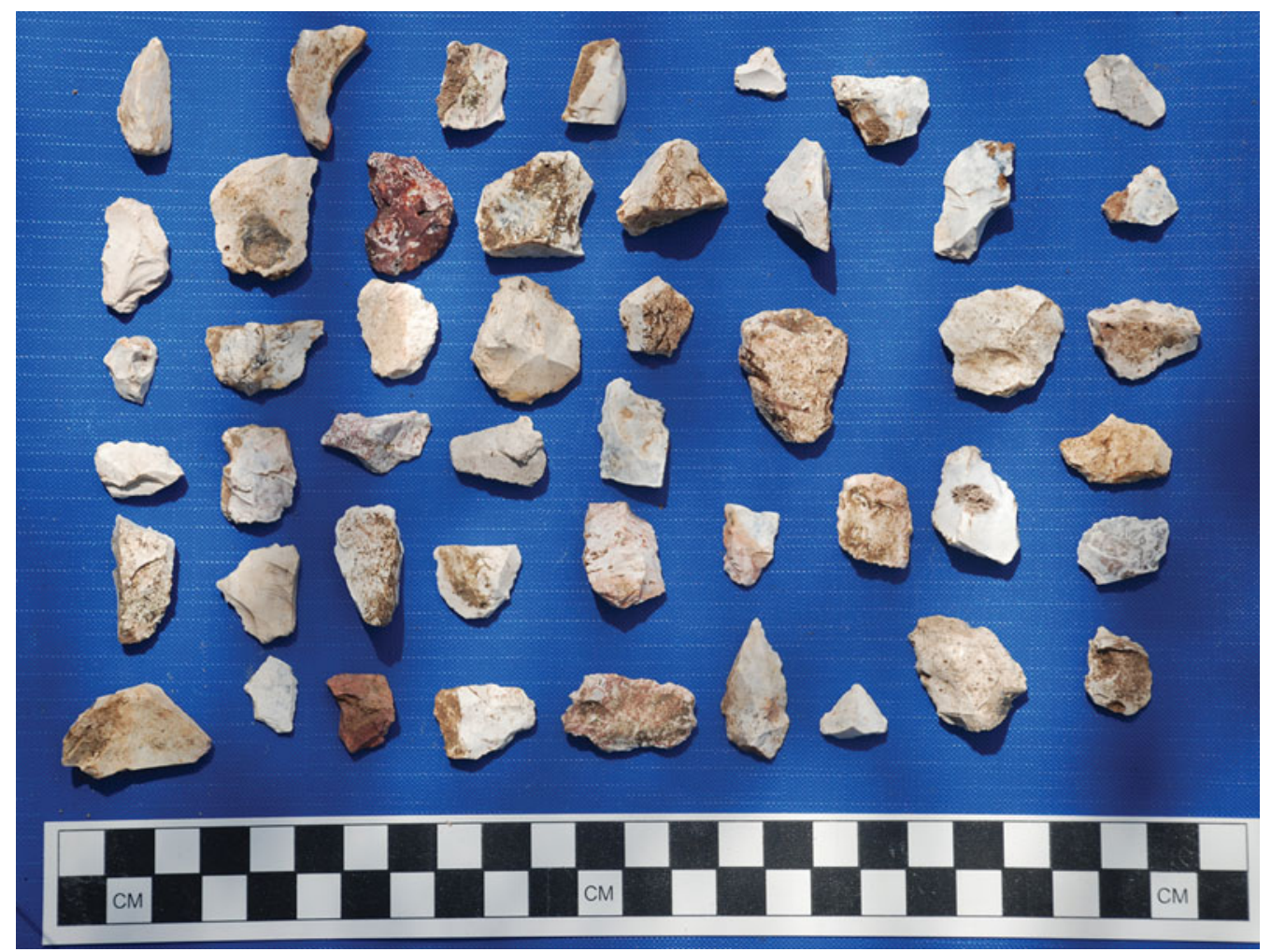

Figure 4. The flake-based lithic assemblage produced with white patinated flint from POI.15.31.
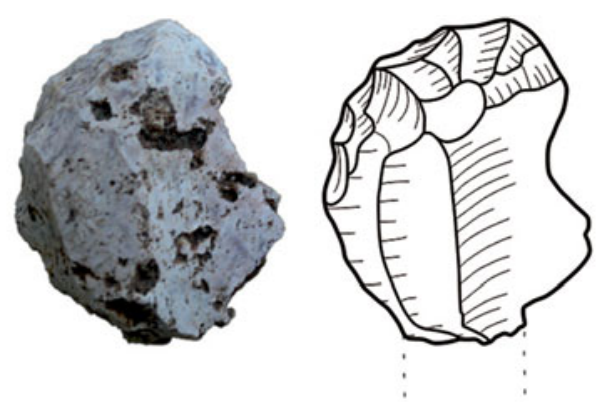

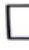

Figure 5. A typical endscraper with semi-abrupt retouch from POI.15.31 (drawing by G. Öz̧̧olak and E. Sezgin). (around 10 per cent of the assemblage) can be attributed to a specific tool type: three endscrapers, three notches and six retouched flakes. The endscrapers were made on flakes and are highly reduced (Figure 5). Unretouched flakes dominate the assemblage (63 pieces), with an average length of $27 \mathrm{~mm}$ (ranging from 14-70mm; standard deviation: $9.14 \mathrm{~mm}$ ). Only three blades are represented, of which two are crested. There are five cores in the assemblage, including one blade core.

The technology encountered at POI.15.31 is in no way comparable to Eastern Mediterranean Epipalaeolithic or Pre-Pottery Neolithic industries. Moreover, neither technological nor typological similarities can be identified with the assemblage from the open-air site of Ouriakos on Limnos (Efstratiou et al. 2014). As far as preliminary (C) Antiquity Publications Ltd, 2016 
observations permit, the industry represented at POI.15.31 resembles Aegean Mesolithic chipped stone assemblages identified at Franchthi lithic phase VII, Kerame 1 on Ikaria, Maroulas on Kythnos, and Stélida on Naxos (Perlès 1999; Sampson et al. 2012; Carter et al. 2014). This findspot represents virtually the only known Mesolithic site from the western coast of Turkey that can be compared with Early Holocene forager sites elsewhere in the Aegean. As such, POI.15.31 merits more detailed investigation in future fieldwork seasons.

\section{Acknowledgements}

The project is being conducted with the permission of the Turkish Ministry of Culture and Tourism, and is supported by Ege University Research Fund (grant 2015-EDB-005), Groningen University Institute of Archaeology and the Municipality of Karaburun.

\section{References}

Carter, T., D. Contreras, D. Mihailović, T. Moutsiou, N. SKarPelis \& S. DoYle. 2014. The Stélida Naxos Archaeological Project: new data on the Middle Palaeolithic and Mesolithic Cyclades. Antiquity Project Gallery 88(341). Available at: http://antiquity.ac.uk/projgall/carter341 (accessed 13 June 2016).

Efstratiou, N., P. Biagi \& E. Starnini. 2014. Lemnos Adası Ouriakos Epipaleolitik Yerleşimi ve Doğu Akdeniz', in Geç Pleistosen Dönemde İskân Edilmesi Sürecindeki Yeri. Adalya XVII: 1-24.

Galanidou, N., J. Cole, G. Iliopoulos \& J. McNABв. 2013. East meets West: the Middle Pleistocene site of Rodafnidia on Lesvos, Greece. Antiquity Project Gallery 87(336). Available at: http://antiquity.ac.uk/projgall/galanidou336/ (accessed 13 June 2016).

KANSU, Ş.A. 1963. Note préliminaire sur le Paléolithique de la région egéenne. Belleten XXVII/107: 485-90.
- 1969. İzmir Dolaylarında Bulunan İkinci Bir Alt Paleolitik Alete Ait Not. Belleten XXXIII/129: 79-81.

KoşAY, H.Z. \& H. GÜLTEKIN. 1949. Karaburun (İzmir) Çakmak Civa Madeninde Öntarih Buluntuları. Türk Tarih, Arkeologya ve Etnografya Dergisi V: 16-25.

PERLÈs, C. 1999. Long-term perspectives on the occupation of the Franchthi Cave: continuity and discontinuity, in G.N. Bailey, E. Adam, G. Bailey, E. Panagopolou \& C. Perlès (ed.) The Palaeolithic archaeology of Greece and adjacent areas: Proceedings of the ICOPAG Conference. Ioannina: 311-18. Athens: British School at Athens.

Sampson, A., M. Kaczanowska \& J.K. Kozlowski. 2012. Mesolithic occupations and environments on the Island of Ikaria, Folia Quaternaria 80: 5-40.

Uhri, A., A.K. ÖZ \& O. GÜlbay. 2010. Karaburun/Mimas Yarımadası Araştırmaları. Ege Üniversitesi Arkeoloji Dergisi XV: 15-20. 